\title{
Peace economics and peaceful economic policies
}

\section{Raul Caruso}

Raul Caruso is Professor of Economics, Catholic University of the Sacred Heart, Milan, Italy, and Director of the European Center of Peace Science, Integration, and Cooperation, Tirana, Albania. He may be reached at raul.caruso@unicatt.it.

\section{Abstract}

This article outlines pillars of peace economics and peaceful economics policies. It first highlights Kenneth Boulding's contribution to peace economics. In particular, substantial attention is paid to his conception of three systems that govern social life, namely the exchange system, the threat system, and the integrative system. Examples are produced to describe the differences between and among them. Second, in light of Boulding's views, a workable definition of peace is proposed and associated suggestions for peaceful economic policy are made. Three aspects are underlined: The establishment of consensual democracies, the setting of a novel economic policy target - namely the ratio of public education expenditure to military expenditure — and the pursuit of stricter regulations on the international arms trade.

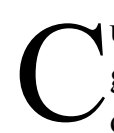
urrent geopolitics and related economic aspects are generating a growing interest among economists in the definition, nature, and scope of peace economics. Along with a definition of peace economics, this article provides its conceptual underpinnings based on the work of Kenneth Boulding.

\section{Peace and peace economics}

To understand properly the nature of peace and peace economics, refer to the seminal work of Kenneth Boulding, published in 1963. He highlighted the theoretical pillars of peace economics by pointing to the interdependence of three systems: the exchange system, the threat system, and the integrative system, named after the dominant character of the interactions between individuals or organizations. All have a clear-cut economic shape. The exchange system is the classic domain of economics. It is the realm of economic interactions characterized by the free, voluntary, and mutually beneficial exchange of goods and services. The price system and the market are expected to generate efficient outcomes for both, individuals and organizations. As predicted by the classic script, exchange can drive welfare improvements for all parties involved. Indeed, the exchange system is productive of overall wealth by definition because it triggers the allocation of resources toward their most efficient uses. The threat system, in contrast, is defined as interactions between rational agents which are characterized by the existence of credible threats. Threat systems have remarkable effects on economic development. They influence the allocation of resources and so affect the development path in the long-run. They can be interpreted as the roots of institutions and thereby shape social outcomes. An integrative system is characterized by unilateral transfers between rational agents (grants). For what they may give, agents do not receive anything directly in return. Instead, benefits accrue indirectly, enhancing the advantages of interaction and trade within the framework of institutional sets of rules. For example, if a country gains access to an international organization (say, the World Trade Organization, WTO), it can expect to harvest not just a one-time, immediate benefit as in the exchange system but a continuous stream of benefits over the long run. In practice, it gains access at a certain point in time by means of a unilateral commitment and it will be rewarded in the future with positive income gains. In terms of nation-states, the integrative systems overlaps with cooperative and generally friendly relations.

The three systems do not exist in pure form. They coexist and interact. All real-world scenarios are hybrid scenarios. For example, relations between nation-states can be fairly friendly (integrative) on some issues and hostile (characterized by threats) on other issues or simply led by trade interests. The triangle in Figure 1 represents Boulding's line of reasoning. The coordinates of each point within the triangle capture the relative intensity of each system. Relations between any two or more nation-states can be defined by accounting for the different intensities of the three systems. Thus, the existence of a Free Trade Area (FTA) suggests trade-oriented, and mostly friendly, relations among states. Consequently, in Figure 1, the point FTA lies close to the vertex where the exchange system is dominant. Economic integration can take shape under a set of rules that make cooperation sustainable over the long run. Exchange relations are enriched by an integrative system. So, for example, both the European Union (EU) and the WTO exhibit deeper integrative relationships than does a mere FTA. In addition, because the EU is an organization far more 


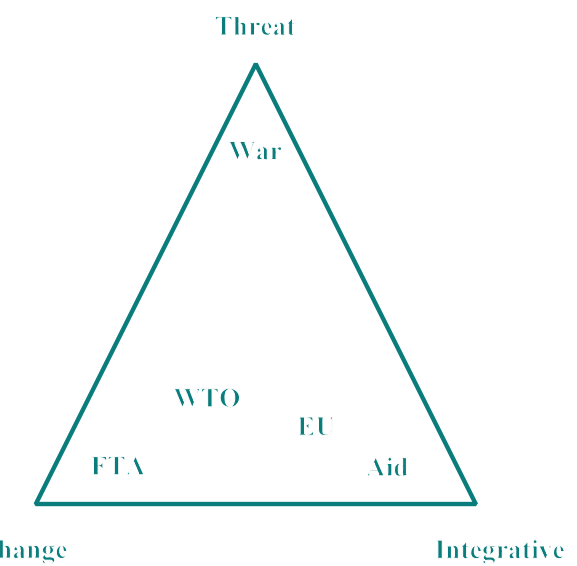

Figure 1: Boulding's three systems. Notes: FTA: Free Trade Area; WTO: World Trade Organization; EU: European Union; Aid: Humanitarian aid, for example.

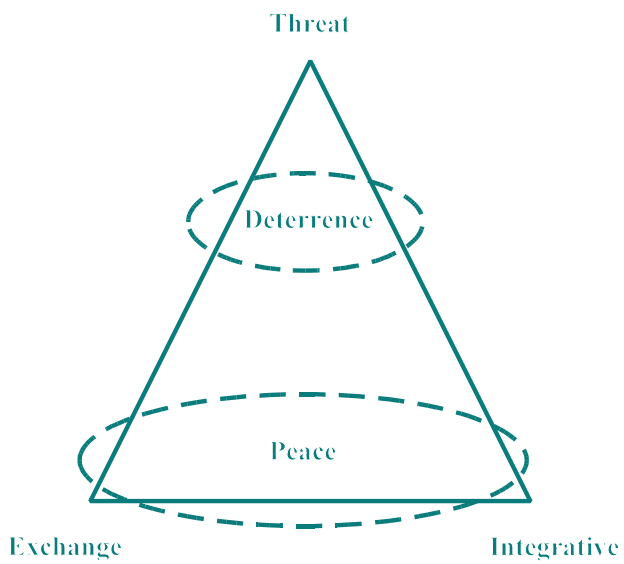

Figure 2: Deterrence and peace.

structured than is the WTO, we say that the EU's integrative component is more intense than that of the WTO. Therefore, within Boulding's triangle, the EU point lies closer to the integrative vertex. Note that the threat component does not disappear; it just gets close to zero. Other illustrative cases are easy to generate. For instance, humanitarian aid flows largely are characterized by unilateral transfers, pointing toward a nonthreat, integrative relation.

In this vein, it is easy to highlight the structural difference between deterrence and peace. Deterrence, arms races, and continuing conflicts all fall into the general category of threat systems. Despite the absence of armed conflict, deterrence is not equivalent to peace. Peace is the scenario in which exchange and integrative systems dominate threat relationships between countries, as illustrated in Figure 2. Viewed this way, the EU is a relative success story in terms of peace: Exchange and integrative relationships dominate over threat interactions.

The dominance of one system over the others is associated with remarkable effects on long-run economic development. Threat systems influence the allocation of resources toward issuing or defending from threat. Consequences of deterrence, conflict, and threat systems include instability and long-run economic decline because of excessive unproductive and destructive activities. Although not necessarily descending into war, threat systems imply heavy investment in weapons and other military equipment, thereby inflating the expenditure into unproductive activities of societies. To understand this, refer to Paul Samuelson's classic resource diversion argument. In economics, he popularized the notions of unproductive and productive activities with a guns versus butter analogy. ${ }^{1}$ Samuelson had Nazi Germany in mind, where the government was committed to increasing military expenditure (guns) at the expense of civilian production (butter). The tradeoff between butter and guns was considered a matter of economic policy.

The distinction between productive and unproductive activities dates back to the Physiocrats, and the concept is still valid today: Some profitable economic activities are not inherently productive and thus do not contribute to an increase of the general welfare of the whole of society. A definition of unproductive activities was provided by Jagdish Bhagwati in 1982. They “... represent ways of making a profit (i.e., income) by undertaking activities which are directly unproductive; that is, they yield pecuniary returns but do not produce goods or services that enter a utility function directly or indirectly via increased production or availability to the economy of goods that enter a utility function. Insofar as such activities use real resources, they result in a contraction of the availability set open to the economy ..." In 1990, William Baumol generalized the argument, explaining how societies' historical development depends on the balance between productive and unproductive activities. He mentions the Middle Ages as an era in which the creation of income and wealth was managed essentially by means of military activities and how economic development and human welfare were undermined by that. In this respect, he remarks that any innovation in military means and in warfare do not contribute more to economic development than would innovations developed in the traditional manufacturing sector. ${ }^{2}$

The ideas posited by Bhagwati and Baumol highlight the tradeoff between civilian and military activities. Both consider a set of unproductive activities that is larger than the subset that includes military expenditure only. For instance, take rent- 
seeking activities, pervasive in many arenas of economic life and often a crucial component of productive sectors. Albeit not directly destructive, rent-seeking is detrimental to economic development in the long run. Albeit competitive, rent-seeking activities are not subject to the free play of market forces. Instead, the market is contested by rational actors who exert irreversible effort or undertake irreversible (licit or illicit) monetary outlays. As the burden of rent-seeking activities increases, the adverse effect on development gets heavier. ${ }^{3}$

Within this context, one can advance a workable definition of peace: Peace is an integrative institutional setting that favors productive at the expense of unproductive activities due to democratic governance, balanced economic interdependence, and long-lasting productivity growth in the long-run. This, in turn, leads to a workable definition of peace economics as in Brauer and Caruso (2013): "Peace economics concerns the economic study and design of political, economic, and cultural institutions, their interrelations, and their policies to prevent, mitigate, or resolve any type of latent or actual violence or other destructive conflict within and between societies." ${ }^{4}$

\section{Suggestions for economic policy}

As the definition indicates, peace economics takes a normative approach. This aligns with Boulding's view: "One could perfectly well suppose a discipline of polemology as a positive science studying conflict in all its aspects, which had no normative implications. Peace research, however, has always been normative, in the sense that it has been practiced by people who are deeply conscious of the pathologies of conflict and who want to make it as cheap and productive as possible." The normative view is also maintained by Walter Isard (1994), Kenneth Arrow (1995), and by Coloumb, Hartley, and Intriligator (2008) who write: "Denouncing war and its economic consequences is not enough. In most economic research, peace remains a result or a pre-condition for economic efficiency. It does not attain the status of a full economic issue. This situation cannot be considered as satisfactory for two main reasons. First, history demonstrates that, in particular, having a market economy is a necessary condition for peace, but is not sufficient ... Second, peace cannot be considered only as a result or an exogenous factor. It is very unsatisfactory to define it as the absence of conflicts or war: this is how defence policy can be defined, not peace. This latter requires an active policy, for it is far from certain that peace will always emerge from given economic conditions. If we truly want peace, then we cannot escape from investing in it!"

Accordingly, I highlight three crucial lines for potential policymaking: the establishment of consensual democracy, the setting a novel economic policy target, and the pursuit of stricter regulations in the international arms trade. ${ }^{6}$ Democracy comes first. It is an integrative system, but it is not necessarily the case that democracies are less prone to intra- or interstate conflicts than are nondemocracies. Democracies are not all equally successful in preventing conflict. In fact, majoritarian democracies often are divisive. For fragmented and post-war societies especially, it is necessary to design and establish a form of democracy suited to prevent the exploitation of recent, and a relapse into renewed, violence (violence recurrence). The political economy to be adopted to secure peace has to depart from classic majoritarian democracy because it does not guarantee that causes of, and opportunities for, conflict can be removed. This is why consensus democracies, as envisioned by Lijphart, would appear to be better suited to secure peace in pluralist and divided societies. Based on power-sharing and decentralization, they fit particularly well to the context of post-conflict or war-torn societies. Decentralized societies can be stable and peaceful. Decentralization can be crucial to manage natural resources and common goods and has been proved to be conflict-abating. In brief, peace economists would start by suggesting decentralization as a pillar of a broader consensus-based democracy. ${ }^{7}$

The second suggestion relates to the target variables commonly used in economic policy. Aware of the long-run detrimental impact of threat systems, I propose a novel policy variable to highlight the balance between the detrimental factor of military expenditure and a long-run driver of development, namely investment in education. As military expenditure undermines development (because of its unproductive nature) there must be a countervailing force which activates productive activities. Thus, I suggest the use of the ratio of public education expenditure to military expenditure (educ/milex) as the relevant policy variable. Table 1 shows the values for this ratio for selected countries.

What emerges, at first glance, is that countries with ratios of about one or less than one are or were involved in acute conflicts (China, Colombia, India, Israel, Russia, the U.K., and the United States) and the other countries much less so, if at all. In the long run, this could be detrimental for social welfare and put at risk the stability of the affected polities, too. Figure 3 links the educ/milex ratio (in 2000) to per capita GDP (in 2013). Again, at first glance, the correlation appears to be strong enough: The higher the past value of the educ/milex ratio (i.e., in 2000), the higher is current GDP per capita (in 2013). Further research will have to be conducted but it may well turn out to be the case that the educ/milex ratio is an adequate measure to capture the potentially detrimental impact of the threat system, descending from excessive spending on 
Table 1: Ratios of public education to military expenditures

$\begin{array}{llllll} & 2000 & 2011 & & 2000 & 2011 \\ \text { Australia } & 2.54 & 2.79 & \text { Japan } & 3.72 & 3.69 \\ \text { Brazil } & 2.28 & 3.67^{* *} & \text { India } & 1.43 & 1.33 \\ \text { Canada } & 4.96 & 4.69 & \text { Israel } & 0.82 & 0.94 \\ \text { China } & 1.01 & \mathrm{n} / \mathrm{a} & \text { Italy } & 2.19 & 2.47 \\ \text { Colombia } & 1.16 & 1.45 & \text { Mexico } & 8.40 & 9.39 \\ \text { France } & 2.23 & 2.44 & \text { U.K. } & 1.87 & 2.46^{* *} \\ \text { Germany } & 3.01 \S & 3.63^{* *} & \text { Russia } & 0.83 & 1.21^{* * *} \\ \text { Spain } & 3.55 & 4.68^{* *} & \text { USA } & 1.85^{*} & 1.16^{* *}\end{array}$

Source: World Bank, World Development Indicators. Notes: ; § 1998; * 2001; **2010;*** 2008.

the relatively unproductive military sector.

Third, and not least, peace economists pay much attention to the international rules governing the arms trade. Currently, the global arms market appears to be - de facto - unregulated. The market is characterized by monopolistic competition. This leads to an increasing variety of weapons and to continuous outlays on military $R \& D$ so as to retain the capacity for product differentiation. While perhaps acceptable with regard to civilian markets, in the military market this increases the global level of insecurity. There is a compelling need to cooperate to effectively regulate the arms market. The first step in this respect is to implement a set of rules and constraints on the arms trade, for instance by implementing the Arms Trade Treaty (ATT). Approved by the UN General Assembly on 2 April 2013 it has, so far, been signed by 130 countries and ratified by 91 . Unfortunately, certain major countries have not signed the ATT (China and Russia) and the United States has signed but not ratified it. Despite that, the ATT has the merit of establishing a principle which is extremely relevant in the eyes of economists: Weapons are unlike any other goods, and peace — as a global public good — should be considered a focal point for policymakers.

In sum, the aim of this article has been to offer workable definitions of peace and of peace economics, both within Kenneth Boulding's general framework of exchange, threat, and integrative economies and also in line with the classic, Physiocratic distinction between productive and unproductive economic activities. Given the inherently normative character of peace economics, suggestions for three types of policies have been made, the pursuit of which may enhance peace.

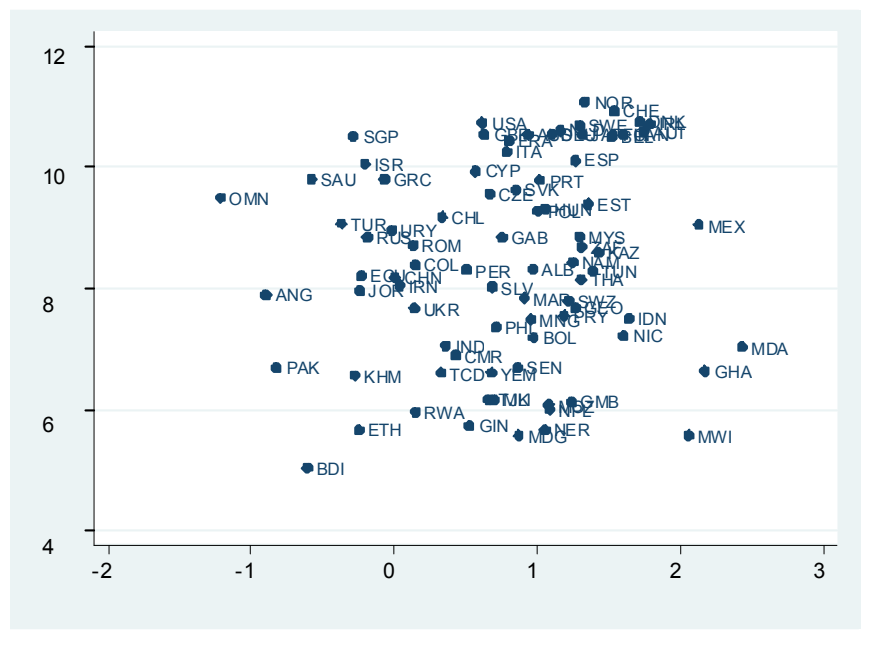

Figure 3: Log of per capita GDP (vertical axis; USD in 2013) as against log of the ratio of education to military expenditure (horizontal axis; USD in 2000).

Notes

1. Before Samuelson popularized the guns and butter analogy in this Foundations of Economic Analysis textbook (1947), it was used, e.g., by J.P. Wernette in a piece entitled "Guns and Butter" (reprinted from Harvard Business Review, and cited in Mendershausen, 1943 [1940], p. 20, note 16).

2. Quote: Bhagwati (1982, p. 989). Baumol: Baumol (1990).

3 . On the impact of rent-seeking by powerful groups on growth see, e.g., Tornell and Lane (1999).

4. Quote: Brauer and Caruso (2013, pp. 151-152).

5. Quotes: Boulding (1978, p. 343); Coulomb, Hartley, and Intriligator (2008, p. 383).

6. The following is based on my recent book, Caruso (2017).

7. Lijphart (1969; 2004). Stable and peaceful: Myerson (2006); Weingast (2014). Natural resource management: Agrawal and Ostrom (2001). Conflict-abating: Murshed, Tadjoeddin, and Chowdury (2009).

\section{References}

Agrawal, A. and E. Ostrom. 2001. "Collective Action, Property Rights, and Decentralization in Resource Use in India and Nepal." Politics and Society. Vol. 29, No. 4, pp. 485-514.

https://doi.org/10.1177/0032329201029004002

Arrow, K.J. 1995. "Some General Observations on the Economics of Peace and War." Peace Economics, Peace Science, and Public Policy. Vol. 2, No. 2, pp. 3-10.

Baumol, W.J. 1990. "Entrepreneurship: Productive, Unproductive, and Destructive." Journal of Political Economy. Vol. 98, No. 5, Part 1, pp. 893-921. 
Bhagwati, J.N. 1982, "Directly Unproductive, Profit-Seeking (DUP) Activities." Journal of Political Economy. Vol. 90, No. 5, pp. 988-1002. https://doi.org/10.1086/261104

Boulding, K.E. 1963. "Towards a Pure Theory of Threat Systems." American Economic Review. Vol. 53, No. 2, pp. 424-434.

Boulding, K.E. 1978. "Future Directions in Conflict and Peace Studies." Journal of Conflict Resolution. Vol. 22, No. 2, pp. 342-354.

https://doi.org/10.1177/002200277802200208

Brauer, J. and R. Caruso. 2013. "Economists and Peacebuilding," pp. 147-158 in Roger Mac Ginty, ed. Handbook of Peacebuilding. London: Routledge.

Caruso, R. 2017. Economia della pace. Bologna: Il Mulino.

Coulomb, F., K. Hartley, and M. Intriligator. 2008 . "Pacifism in Economic Analysis: A Historical Perspective." Defence and Peace Economics. Vol. 19, No. 5, pp. 373-386.

https://doi.org/10.1080/10242690802354378

Isard, W. 1994. "Peace Economics: A Topical Perspective." Peace Economics, Peace Science, and Public Policy. Vol. 1, No. 2, pp. 6-9.

Lijphart, A. 1969. "Consociational Democracy." World Politics. Vol. 21, No. 2, pp. 207-225.

https://doi.org/10.2307/2009820

Lijphart, A. 2004. "Constitutional Design for Divided Societies." The Journal of Democracy. Vol. 15, No. 2, pp. 96-109.

https://doi.org/10.1353/jod.2004.0029

Mendershausen, H. 1943 [1940]. The Economics of War. New York: Prentice-Hall.

Murshed, S.M., M.Z. Tadjoeddin, and A. Chowdury. 2009. "Is Fiscal Decentralization Conflict Abating? Routine Violence and District Level Government in Java." Oxford Development Studies. Vol. 37, No. 4, pp. 397-421. https://doi.org/10.1080/13600810903305224

Myerson, R.B. 2006. "Federalism and Incentives for Success of Democracy." Quarterly Journal of Political Science. Vol. 1, No. 1, pp. 3-23. https://doi.org/10.1561/100.00000002

Tornell, A. and P.R. Lane. 1999. "The Voracity Effect." American Economic Review. Vol. 89, No. 1, pp. 22-46. https://doi.org/10.1257/aer.89.1.22

Weingast, B.R. 2014. "Second Generation Fiscal Federalism: Political Aspects of Decentralization and Economic Development." World Development. Vol. 53, No. 1, pp. $14-25$.

https://doi.org/10.1016/j.worlddev.2013.01.003 